\title{
ECOLOGICAL AND HEALTH RISK ASSESSMENT OF HEAVY METALS POLLUTION IN SOIL AROUND THE THERMAL POWER PLANT "NIKOLA TESLA A"
}

UDC 504.5:546.4/.8:621.311.22(497.11)

\author{
Milan N. Tanić ${ }^{1}$, Mirjana Ćujić ${ }^{2}$, Snežana Dragović ${ }^{2}$, Marko Dakovićc ${ }^{3}$ \\ ${ }^{1}$ Chemical-Biological-Radiological-Nuclear Defense Center, Kruševac, Serbia \\ ${ }^{2}$ University of Belgrade, Vinča Institute of Nuclear Sciences, Belgrade, Serbia \\ ${ }^{3}$ University of Belgrade, Faculty of Physical Chemistry, Belgrade, Serbia
}

\begin{abstract}
Ecological and health hazards were assessed based on the concentrations of selected heavy metals ( $\mathrm{Cd}, \mathrm{Co}, \mathrm{Cr}, \mathrm{Cu}, \mathrm{Fe}, \mathrm{Mn}, \mathrm{Ni}, \mathrm{Pb}$, and $\mathrm{Zn})$ in thirty surface soil samples taken from the sites around the largest Serbian thermal power plant. Ecological risk caused by heavy metals was estimated through pollution indices whose values indicated low to moderate ecological risks. Health hazard associated with residents' exposure to heavy metals in soil was calculated applying the U.S. EPA model. The ingestion of soil was the most important exposure pathway. The risk assessment showed that exposure to $\mathrm{Co}, \mathrm{Fe}$, and $\mathrm{Mn}$ would result in an unacceptable non-carcinogenic risk for children. $\mathrm{Cr}$ and $\mathrm{Pb}$ were reported to significantly contribute to a carcinogenic risk, while total carcinogenic risk remained within the acceptable non-hazardous range.
\end{abstract}

Key words: environmental pollution, soil, heavy metal, pollution indices, Risk Assessment Information System, "Nikola Tesla A"

\section{INTRODUCTION}

Coal-fired thermal power plants (TEPP) are one of the major sources of environmental pollution. The percentage of coal in world energy production in 2012 was $41 \%$, and it is going to rise to $31 \%$ in 2040 , which means that coal will remain fossil fuel with the largest contribution to energy production on a world scale [1]. Suspended particles, oxides of carbon, sulfur and nitrogen are the main pollutants originating from coal combustion. The principal result of combustion of organic compounds in coal is the release of hydrocarbons [2]; however, in terms of inorganic substances, such as heavy metals, coal combustion contributes to their concentrations in combustion by-products [3]. Heavy metals

Received August 5, 2019 / Accepted September 16, 2019

Corresponding author: Milan N. Tanić

CBRN Defense Center, Belgrade, Serbia

E-mail: milantanic@yahoo.com 
are pollutants of special concern because they are persistent and do not undergo chemical or biological degradation, and consequently, their concentration will remain constant over time once they reached soil [4]. Disposal of combustion by-products and atmospheric emission of fly ash and flue gases are two main pathways for dispersion of heavy metals in the soil surrounding coal-fired TEPP.

Very often TEPPs are situated in densely populated areas where other point and nonpoint pollution sources are present, and the distinction of pollution coming from TEPP is a difficult task. In that respect, delineation of the spatial distribution of heavy metals in soil is of vital importance. Geostatistics in combination with geographic information systems (GIS) enables quantification of the spatial features of investigated variables and has been frequently applied in environmental studies for investigation and mapping of soil pollution [5-7]. Moreover, the analysis of heavy metal distribution in soils of populated regions is a baseline for assessment of ecological and human health risk [8].

For ecological risk estimation, various pollution indices have been used efficiently in many environmental studies for assessment of soil pollution status concerning uncontaminated soils in general [2,7,9-11].

Heavy metals may reach the human body as a result of dietary and non-dietary intake (direct inhalation, ingestion, and dermal absorption). Most heavy metals have adverse health effects, but some heavy metals such as $\mathrm{Fe}, \mathrm{Mn}, \mathrm{Co}, \mathrm{Cu}, \mathrm{Zn}$, and $\mathrm{Ni}$ in minute amounts act as micronutrients, whereas some metals (e.g. $\mathrm{Cd}, \mathrm{Cr}, \mathrm{Pb}$ ) have carcinogenic properties. Bearing that in mind, the population living near TEPPs should be considered to be exposed to soil and ash contaminated by heavy metals, and the health risk should be continuously or at least periodically estimated.

Thermoelectric power plants participate with more than two thirds in the total capacities of the electric power industry of Serbia, and all major TEPPs use lignite as a fuel [12]. Although numerous studies have dealt with soil pollution by heavy metals originating from the Serbian TEPPs, none of them have tried to evaluate associated health risk $[9,13]$. The objectives of the present study were to: (i) assess ecological risk by calculating different pollution indices; (ii) quantify carcinogenic and non-carcinogenic health hazard for residents associated with heavy metals in the surface soil around the largest TEPP in Serbia, and (iii) outline spatial distribution of heavy metals in soil by means of spatial analysis.

\section{MATERIALS AND METHODS}

\subsection{Study area}

The TEPP "Nikola Tesla A" is the largest individual TEPP in Serbian electric power industry. It is located near Obrenovac, on the right bank of the Sava River, $35 \mathrm{~km}$ upstream from Belgrade. The total capacity is $1.65 \mathrm{GW}$, and the average lignite consumption is $2.51 \mathrm{Mt}$ per hour. TEPP produces and disposes approximately 2.4 million tons of alkaline ash per year. Ash deposits cover a total surface of 900 ha of the study area [14].

The climate is moderate-continental with average monthly temperatures from $0.1{ }^{\circ} \mathrm{C}$ in January to $22.1^{\circ} \mathrm{C}$ in July. The mean annual precipitation is $670 \mathrm{dm}^{3} \mathrm{~m}^{-2}$. Prevailing winds are variable and tend to primarily blow from the south-southeast, west-northwest, southeast, and west directions with the mean annual wind speed of $2.33 \mathrm{~m} \mathrm{~s}^{-1}$ [15]. 


\subsection{Soil sampling and heavy metal analysis}

Surface soil samples were collected at 30 locations in the vicinity of the TEPP "Nikola Tesla A", following a systematic radial sampling grid covering the period 2011-2013. The sampling points were distant from the TEPP 1, 2, 4, 6, 8, and $10 \mathrm{~km}$ to the west $(\mathrm{W})$, southwest (SW), south (S), southeast (SE), and east (E) direction (later shown in Figure 2). Method 3050B of the United States Environmental Protection Agency (US EPA) was used for the digestion of soil samples. Total concentrations of $\mathrm{Cd}, \mathrm{Co}, \mathrm{Cr}, \mathrm{Cu}, \mathrm{Fe}, \mathrm{Mn}, \mathrm{Ni}, \mathrm{Pb}$, and $\mathrm{Zn}$ were measured by atomic absorption spectrometry. The procedures of soil sampling, sample preparation, and analysis were described in detail in our previous paper [16].

\subsection{Pollution indices}

The level of soil pollution by selected heavy metals in the study area in comparison with mean values of their concentrations in European uncontaminated topsoils [17] were evaluated by enrichment factor $(E F)$ calculated according to the adjusted formula proposed by Zoller et al. [18]:

$$
E F=\left[c_{\mathrm{sa}}(\mathrm{HM}) / c_{\mathrm{sa}}(\mathrm{Fe})\right] /\left[c_{\mathrm{Eur}}(\mathrm{HM}) / c_{\text {Eur }}(\mathrm{Fe})\right]
$$

where $c(\mathrm{HM})$ and $c(\mathrm{Fe})$ are the concentrations of particular heavy metal and Fe in soil, respectively, and the subscripts "sa" and "Eur" denote those concentrations in the study area and Europe.

The geo-accumulation index, $I_{\text {geo }}$, was used originally for comparison of the current concentration of a specific element in particular media to its level in the preindustrial era. In this work, $I_{\text {geo }}$ was calculated according to the equation below [19]:

$$
I_{\text {geo }}=\log _{2}\left[c_{\mathrm{sa}}(\mathrm{HM}) / k \times c_{\text {Eur }}(\mathrm{HM})\right]
$$

where $k$ is a factor with value 1.5 that accounts possible variations in background levels for a given metal due to lithospheric effects and minor anthropogenic influences.

Contamination factor, $C F$, represents the ratio between the measured concentration of each heavy metal in the soil sample from the study area and its concentration in unpolluted soil [20] and is given by equation (3).

$$
C F=c_{\mathrm{sa}}(\mathrm{HM}) / c_{\text {Eur }}(\mathrm{HM})
$$

Soil classification based on $E F$ groups [10], $I_{\text {geo }}$ classes [19] and $C F$ grades [20] are indicated in Figure 1.

To estimate the overall level of pollution caused by all heavy metals investigated, the pollution load index ( $P L I)$ was calculated for each sampling point using relation (4) based on $C F$ for all elements [21].

$$
P L I=\sqrt[n]{C F\left(\mathrm{HM}_{1}\right) \times C F\left(\mathrm{HM}_{2}\right) \times \cdots \times C F\left(\mathrm{HM}_{n}\right)}
$$

When $P L I>1$, it is an indication that soil of interest is polluted by heavy metals in comparison with the reference soil. 


\subsection{Health risk assessment}

The potential non-cancerogenic and carcinogenic risk for children and adults were estimated for exposures to minimal, mean and maximal total measured concentration of selected heavy metals. In the case of $\mathrm{Cr}$, 6:1 ratio of $\mathrm{Cr}(\mathrm{III}): \mathrm{Cr}(\mathrm{VI})$ was used as a reasonable estimate of the relative abundance of the two species as recommended by the US EPA. Namely, $\mathrm{Cr}(\mathrm{III})$ is an essential dietary nutrient, while $\mathrm{Cr}(\mathrm{VI})$ is a carcinogen to humans [22].

US EPA risk assessment model, which is fully accessible through Risk Assessment Information System (RAIS) [22] was exploited for risk calculation taking into account direct ingestion of soil, inhalation of resuspended particles and dermal exposure to heavy metals in soil adhered to the skin.

The basic equation for the calculation of excess lifetime cancer risk (ELCR) is:

$$
E L C R=C D I \times S F
$$

where $E L C R$ represents the unitless probability of an individual developing cancer over a lifetime; $C D I$ is a chronic daily intake expressed in $\mathrm{mg} \mathrm{kg}^{-1} \mathrm{day}^{-1}$, and $S F$ is a cancer slope factor in $\mathrm{mg}^{-1} \mathrm{~kg}$ day.

Non-carcinogenic risk is expressed as the hazard quotient $(H Q)$, a unitless number that does not have the meaning of probability. Hazard quotient for single heavy metal is calculated using equation (6):

$$
H Q=C D I \times R f D^{-1}
$$

where $R f D$ is chronic reference dose $\left(\mathrm{mg} \mathrm{kg}^{-1} \mathrm{day}^{-1}\right)$. The value of $H Q$ should be less than unity to consider risk from systemic toxicity negligible.

The total cancer risk, $E L C R_{\text {total, }}$, is calculated as a sum of all $E L C R$ for all heavy metals investigated and exposure routes considered. The overall non-carcinogenic risk is expressed as hazard index, $H I$, a unitless number equal to the sum of all $H Q$ for all heavy metals and all exposure routes accounted for. If $H I>1$ significant non-cancerogenic toxicity could be expected from a mixture of heavy metals.

Chronic daily intakes for carcinogenic risk for ingestion of soil, $C D I_{\text {ing,cancer }}\left(\mathrm{mg} \mathrm{kg}^{-1} \mathrm{day}^{-1}\right)$, non-carcinogenic risk for soil ingestion, $C D I_{\text {ing,nc }}\left(\mathrm{mg} \mathrm{kg}^{-1}\right.$ day $\left.^{-1}\right)$, inhalation of particulates emitted from soil for carcinogenic and non-carcinogenic risk, $C D I_{\mathrm{inh}}\left(\mathrm{mg} \mathrm{m}^{-3}\right)$, and cancerogenic and non-carcinogenic risk due to dermal contact with soil, $C D I_{\text {derm }}$ $\left(\mathrm{mg} \mathrm{kg}^{-1} \mathrm{day}^{-1}\right)$, were obtained using formulae (7-10), respectively:

$$
\begin{gathered}
C D I_{\text {ing,cancer }}=c(\mathrm{HM}) \times E F \times I F \times A T^{-1} ; \\
I F=I R_{\text {adult }} \times E D_{\text {adult }} \times B W_{\text {adult }}^{-1}+I R_{\text {child }} \times E D_{\text {child }} \times B W_{\text {child }}^{-1} \\
C D I_{\text {ing,nc }}=c(\mathrm{HM}) \times E F \times E D \times I R \times A T^{-1} \times B W^{-1} \\
C D I_{\text {inh }}=c(\mathrm{HM}) \times E F \times E D \times\left(P E F^{-1}+V F^{-1}\right) \times\left(E T_{\text {out }}+E T_{\text {in }}+D F_{\text {in }}\right) \times A T^{-1} \\
C D I_{\text {derm }}=c(\mathrm{HM}) \times E F \times E D \times S A \times A F \times A B S \times B W^{-1} \times A T^{-1}
\end{gathered}
$$

where $c(\mathrm{HM})$ is the concentration of particular heavy metal in soil $\left(\mathrm{mg} \mathrm{kg}^{-1}\right)$; $E F$ is exposure frequency (350 day year $\left.{ }^{-1}\right)$; IF is intake factor; $A T$ is averaging time for 
cancerogenesis (365 day year ${ }^{-1} \times 70$ years) and non-cancerogenesis (365 day year $\left.{ }^{-1} \times E D\right)$; $I R_{\text {adult }}$ and $I R_{\text {child }}$ are soil ingestion rates for adults $\left(100 \mathrm{mg} \mathrm{day}^{-1}\right)$ and children (200 mg day $\left.{ }^{-1}\right) ; E D_{\text {adult }}$ and $E D_{\text {child }}$ are exposure duration for adults (70 years) and children (6 years); $B W_{\text {adult }}$ and $B W_{\text {child }}$ are body weights for adults $(70 \mathrm{~kg})$ and children $(15 \mathrm{~kg}) ; P E F$ is a particulate emission factor (site-specific, $\left.\mathrm{m}^{3} \mathrm{~kg}^{-1}\right) ; V F$ is volatilization factor (contaminant specific, $\left.\mathrm{m}^{3} \mathrm{~kg}^{-1}\right) ; E T_{\text {out }}$ and $E T_{\text {in }}$ are exposure times outdoor (0.073) and indoor (0.683); $D F_{\text {in }}$ is dilution factor indoor (0.4); $S A$ is available surface area in $\mathrm{m}^{2}$ day $^{-1}$ ( 0.28 for children, 0.57 for adults); $A F$ is resident soil adherence factor in $\mathrm{mg} \mathrm{cm}^{-2}$ ( 0.2 for children, 0.07 for adults); and $A B S$ is absorption factor ( 0.001 ).

Slope factors and reference doses considered here were taken from the RAIS compilation where toxicological profiles for all heavy metals investigated can be found [22].

\subsection{Statistical analysis}

The statistical software SPSS 20.0 was used for statistical analysis. Geostatistical data were processed and spatial modeling was carried out by Golden Software's Surfer $12^{\odot}$ application. Inverse distance weighting was used as the interpolation method. This method presumes that the influence of the variable used for calculation is decreasing with the increase of distance from the point where the value of the variable is known [5].

\section{RESULTS AND DISCUSSION}

\subsection{Heavy metal concentration in analyzed soils}

A statistical summary for concentrations of analyzed heavy metals is given in Table 1 . Compared to maximal limit values (LV) for concentrations of heavy metals in soil valid for European Union [23], higher content was measured only for $\mathrm{Ni}$ in 21 samples.

Table 1 Descriptive statistics of heavy metal concentrations $c(\mathrm{HM})$ in the soil of the study area

\begin{tabular}{lrrrrrrrrr}
\hline Parameter & \multicolumn{10}{c}{$\mathrm{c}(\mathrm{HM}) / \mathrm{mg} \mathrm{kg}^{-1}$} & \multicolumn{1}{c}{} \\
\cline { 2 - 11 } & $\mathrm{Cd}$ & \multicolumn{1}{c}{$\mathrm{Co}$} & \multicolumn{1}{c}{$\mathrm{Cr}$} & $\mathrm{Cu}$ & $\mathrm{Fe}$ & $\mathrm{Mn}$ & $\mathrm{Ni}$ & $\mathrm{Pb}$ & $\mathrm{Zn}$ \\
\hline Mean & 0.89 & 17.1 & 66.6 & 36.0 & 38040 & 455 & 90.4 & 58.1 & 108 \\
Median & 0.74 & 17.7 & 63.3 & 33.6 & 37610 & 458 & 98.2 & 60.3 & 87.0 \\
Std. dev. & 0.49 & 3.7 & 20.9 & 13.1 & 6290 & 125 & 32.2 & 16.4 & 45.4 \\
Min & 0.41 & 10.9 & 21.8 & 11.5 & 22930 & 206 & 31.7 & 16.9 & 59.2 \\
Max & 2.45 & 23.5 & 110 & 64.6 & 51270 & 827 & 147.1 & 91.5 & 252 \\
\hline LV [23] & 3 & - & - & 140 & - & - & 75 & 300 & 300 \\
TV [24] & 0.8 & 9 & 100 & 36 & - & - & 35 & 85 & 140 \\
RV [24] & 13 & 190 & 380 & 190 & - & - & 100 & 530 & 720 \\
Europe [17] & 0.284 & 8.91 & 32.6 & 16.4 & 21700 & 524 & 30.7 & 23.9 & 60.9 \\
\hline
\end{tabular}

In environmental studies, the target (TV) and remediation (RV) values defined by Dutch soil quality guidelines [24] are widely recognized as an indication for serious deterioration of soil and as such have been incorporated in Serbian legislation for soil not used for agricultural production. Concentrations of $\mathrm{Cd}, \mathrm{Cr}, \mathrm{Cu}, \mathrm{Ni}, \mathrm{Pb}$, and $\mathrm{Zn}$ exceeded TVs by $43 \%, 7 \%, 47 \%, 93 \%, 7 \%$, and $20 \%$, respectively. More importantly, none of the heavy metal concentrations is higher than corresponding RVs. 
Table 2 Average heavy metal contents $\left(\mathrm{mg} \mathrm{kg}^{-1}\right)$ in the soil around TEPPs in Europe

\begin{tabular}{lcrcrr}
\hline Heavy metal & Greece [25] & Turkey [3] & Slovakia [26] & Romania [27] & Croatia [28] \\
\hline $\mathrm{Cd}$ & 0.5 & 6.29 & 0.5 & 0.30 & 0.42 \\
$\mathrm{Co}$ & 21.9 & - & - & 11.6 & - \\
$\mathrm{Cr}$ & 346 & 70.5 & 21.2 & - & 184.8 \\
$\mathrm{Cu}$ & 36.9 & 59.5 & 18.9 & 29.2 & 215.7 \\
$\mathrm{Fe}$ & 52300 & 14630 & - & - & - \\
$\mathrm{Mn}$ & 1000 & - & - & 525 & - \\
$\mathrm{Ni}$ & 287 & 89.8 & 19.3 & 45.2 & - \\
$\mathrm{Pb}$ & 17.2 & 26.7 & 29.1 & 70.2 & 137.4 \\
$\mathrm{Zn}$ & 80 & 89.2 & 84.8 & 100 & 415.7 \\
\hline
\end{tabular}

Table 2 summarizes mean heavy metal contents in soils around coal-fired power plants in different European counties close to Serbia [3, 25-28]. Heavy metal concentrations reported in this work were comparable with those concentrations, with certain differences mostly related to the soil parent material, type of the coal used in TEPP, or influence of other anthropogenic sources of pollution.

\subsection{Ecological risk assessment}

The pollution indices presented in Table 3 and Fig. 1, were calculated using the mean concentrations of heavy metals derived from aqua regia digested samples of European uncontaminated soil $(0-25 \mathrm{~cm})$ listed in Table 1 [17].

Table 3 Mean, minimal and maximal values of enrichment factor $(E F)$, contamination factor $(C F)$ and geoaccumulation index $\left(I_{\text {geo }}\right)$ for heavy metals in investigated soil

\begin{tabular}{lccccccccc}
\hline Heavy & \multicolumn{3}{c}{$E F$} & \multicolumn{3}{c}{$C F$} \\
metal & Mean & Min & Max & Mean & Min & Max & Mean & Min & Max \\
\hline Cd & 1.78 & 0.82 & 4.89 & 3.14 & 1.44 & 8.63 & 3.01 & 1.44 & 8.63 \\
$\mathrm{Co}$ & 1.13 & 0.70 & 2.13 & 1.92 & 1.23 & 2.64 & 0.32 & -0.29 & 0.81 \\
$\mathrm{Cr}$ & 1.19 & 0.46 & 1.97 & 2.04 & 0.67 & 3.38 & 0.37 & -1.17 & 1.17 \\
$\mathrm{Cu}$ & 1.30 & 0.30 & 2.30 & 2.19 & 0.70 & 3.94 & 2.14 & 0.38 & 3.94 \\
$\mathrm{Fe}$ & - & - & - & 1.75 & 1.06 & 2.36 & 0.21 & -0.51 & 0.66 \\
$\mathrm{Mn}$ & 0.50 & 0.24 & 0.90 & 0.87 & 0.39 & 1.58 & -0.84 & -1.93 & 0.07 \\
$\mathrm{Ni}$ & 1.69 & 0.70 & 2.67 & 2.95 & 1.03 & 4.79 & 0.86 & -0.54 & 1.68 \\
$\mathrm{~Pb}$ & 1.43 & 0.43 & 2.72 & 2.43 & 0.71 & 3.83 & 0.63 & -1.08 & 1.35 \\
$\mathrm{Zn}$ & 1.01 & 0.59 & 1.90 & 1.78 & 0.97 & 4.13 & 0.14 & -0.63 & 1.46 \\
\hline
\end{tabular}

According to the mean $E F$ values ( 0.50 for Mn to 1.78 for $\mathrm{Cd}$ ) investigated soils are soils without minimal enrichment in comparison with reference soils. Nonetheless, Fig. 1 shows that with respect to $\mathrm{Cd}, \mathrm{Cu}, \mathrm{Ni}$, and $\mathrm{Pb}$ a significant number of samples $(10,4,9$ and 4 , respectively) were moderately enriched, which may imply their anthropogenic origin. Zacháry et al. reported $E F \geq 2$ for $\mathrm{Ni}$ and $\mathrm{Cu}$, whereas $\mathrm{Zn}, \mathrm{Pb}$, and $\mathrm{Cd}$ had $E F$ between 1.2 and 1.8 for urban soil in the Ajka, town in Hungary affected by large lignitebased TEPP and lignite opencast mines [7]. The $E F$ values obtained in the study on heavy metals in the soil around three coal-fired power plants in South Africa revealed no soil 
enrichment in $\mathrm{Mn}$ and $\mathrm{Fe}$, moderate enrichment in $\mathrm{Cd}, \mathrm{Cr}, \mathrm{Cu}$, and $\mathrm{Zn}$, and significant enrichment in $\mathrm{Ni}$ and $\mathrm{Pb}$ content [11].
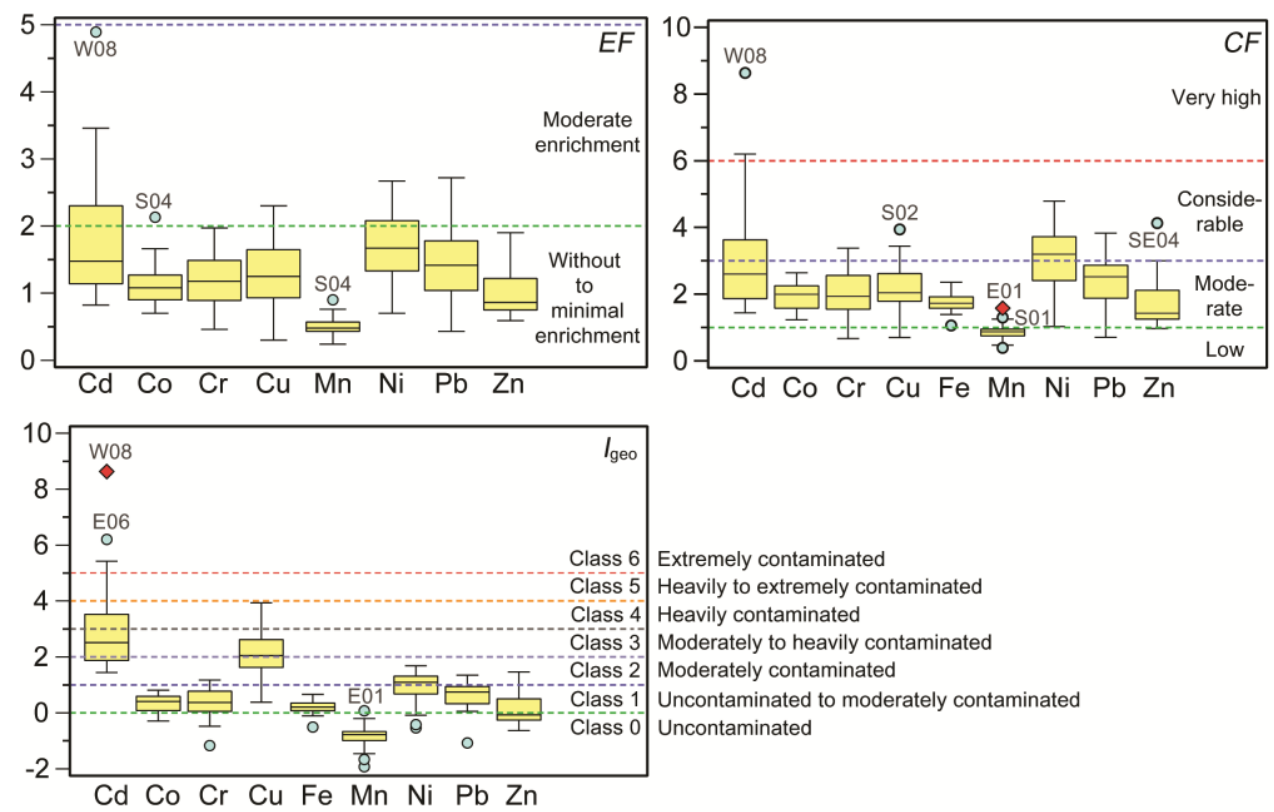

Fig. 1 Box-plot diagram of pollution indices $(E F-$ enrichment factor, $C F-$ contamination factor, $I_{\mathrm{geo}}-$ geoacumulation index) for analyzed heavy metals

Based on the mean values of $C F$, the soil of the study area was depleted in terms of Mn, considerably contaminated by $\mathrm{Cd}$, and moderately contaminated by other heavy metals. However, a certain number of sampling sites were considerably endangered by the high content of $\mathrm{Cd}, \mathrm{Cr}, \mathrm{Cu}, \mathrm{Ni}, \mathrm{Pb}$, and $\mathrm{Zn}$, but it was significant only for $\mathrm{Cd}$ (8 samples) and $\mathrm{Ni}$ (17 samples). A very high $C F$ value for $\mathrm{Cd}$ was recorded only for three locations (E01, E06, and W08). The mean $C F$ values for $\mathrm{Pb}, \mathrm{Cd}, \mathrm{Cu}, \mathrm{Mn}, \mathrm{Zn}, \mathrm{Fe}$, and $\mathrm{Cr}$ of $122,20,8.2,4.4,3.4,1.7$, and 1.1, respectively were reported for the Korba city (India) near the richest coal deposits in India and four TEPPs. Such high values of $C F$ for these heavy metals (especially $\mathrm{Pb}$ and $\mathrm{Cd}$ ) were attributed to continuous coal exploitation, including burning and mining [29].

The $I_{\text {geo }}$ values show that soil samples were uncontaminated to moderately contaminated (classes 0-2), considering $\mathrm{Co}, \mathrm{Cr}, \mathrm{Fe}, \mathrm{Mn}, \mathrm{Ni}, \mathrm{Pb}$, and $\mathrm{Zn}$ together with $27 \%$ and $43 \%$ of the samples regarding $\mathrm{Cd}$ and $\mathrm{Cu}$ content, respectively. Related to $\mathrm{Cu}$, the rest of the samples were classified as moderate to heavily contaminated (class 3 and 4). Among metals, $\mathrm{Cd}$ showed the highest accumulation in soil with 53\% of the samples belonging to classes 3 and 4 , while one and five samples were in class 5 and 6 , respectively.

The $P L I$ varied from 1.41 to 2.66 , and the average value of 1.92 demonstrates that all sampling sites have suffered from pollution from multiple heavy metals to some extent. Furthermore, all $P L I>2$ matched sampling sites taken from the eastern and south-eastern transects which correspond to downwind directions of prevalent winds. 


\subsection{Spatial distribution of heavy metals in soil}

The isoconcentration contour maps for all heavy metals of interest are illustrated in Fig. 2. No regular trends can be observed, but generally, it can be noted that the most contaminated sites were located along eastern and south-eastern sampling directions. Those directions correspond to the downwind area of western and north-western winds with the strongest influence on the aerial distribution of fly ash from ash deposit, as well as flue gases from the TEPP. A considerable influence of predominant wind direction on heavy metal deposition was reported by other similar studies $[3,6,8,9,26]$. The discrepancy from this pattern was noticed only for Mn whose content was quite evenly distributed over the investigated area, suggesting that parent material was a dominating factor that influenced $\mathrm{Mn}$ spatial variability. Despite this, elevated Mn levels can be noticed in the soil close to the TEPP and ash dump. Research of Popovic et al. demonstrated that Mn was continuously leached during and after transport of ash pointing out that elevated Mn concentrations in this part of the study area could be a consequence of transport of ash/water suspension [13].

A detailed inspection of Fig. 2 shows that concentrations of most heavy metals (except $\mathrm{Cu}$ ) were relatively higher in the closest proximity of the TEPP. Hence, it can be deduced that there has been an input of these elements from the TEPP or ash deposit. Raja et al. found higher content of fly ash-fugitive dust in close proximity of TEPPs which had led to a $\mathrm{pH}$ increase and higher accumulation of heavy metals [6].

Apart from soil samples collected from the vicinity of the TEPP, the highest Co concentrations were determined in sites positioned eastward from the Kolubara River where Eutric Cambisols are present, contrary to the eastern part of the study area consisting of alluvial soil. According to Kabata-Pendias, Co concentrations in Cambisols are higher than in other soil types rich in organic matter like alluvial deposits are, pointing out the pedogenic origin of Co [30].

Certain similarities can be spotted for $\mathrm{Cd}$ and $\mathrm{Zn}$ distribution which is particularly evident in the eastern part of the study area. Petrotou et al. ascribed the high concentration of these elements to the deposition of large fly ash particles in the vicinity of the TEPPs in northwestern Greece [25]. Airborne Cd emission from coal-fired electricity generation has been recognized as the most important atmospheric pollution source in the European Union, with the average annual release of $53 \mathrm{~kg}$ Cd per single TEPP [31]. All together suggests that $\mathrm{Cd}$ and $\mathrm{Zn}$ concentrations in the soil are likely to be related to the atmospheric deposition of fly ash from the stacks.

The concentration of Fe did not differ significantly at sites more distant from the TEPP reflecting its natural origin. Nonetheless, it is known that soil response to the deposition of fly ash from the TEPPs is the increase of soil $\mathrm{pH}$ through acidity neutralization [6], and that alkaline conditions promote precipitation of Fe [30]. These lands support the assumption that higher concentrations in soil adjoining the TEPP reflect airborne deposition of fly ash particles that has changed the geogenic content of Fe. 

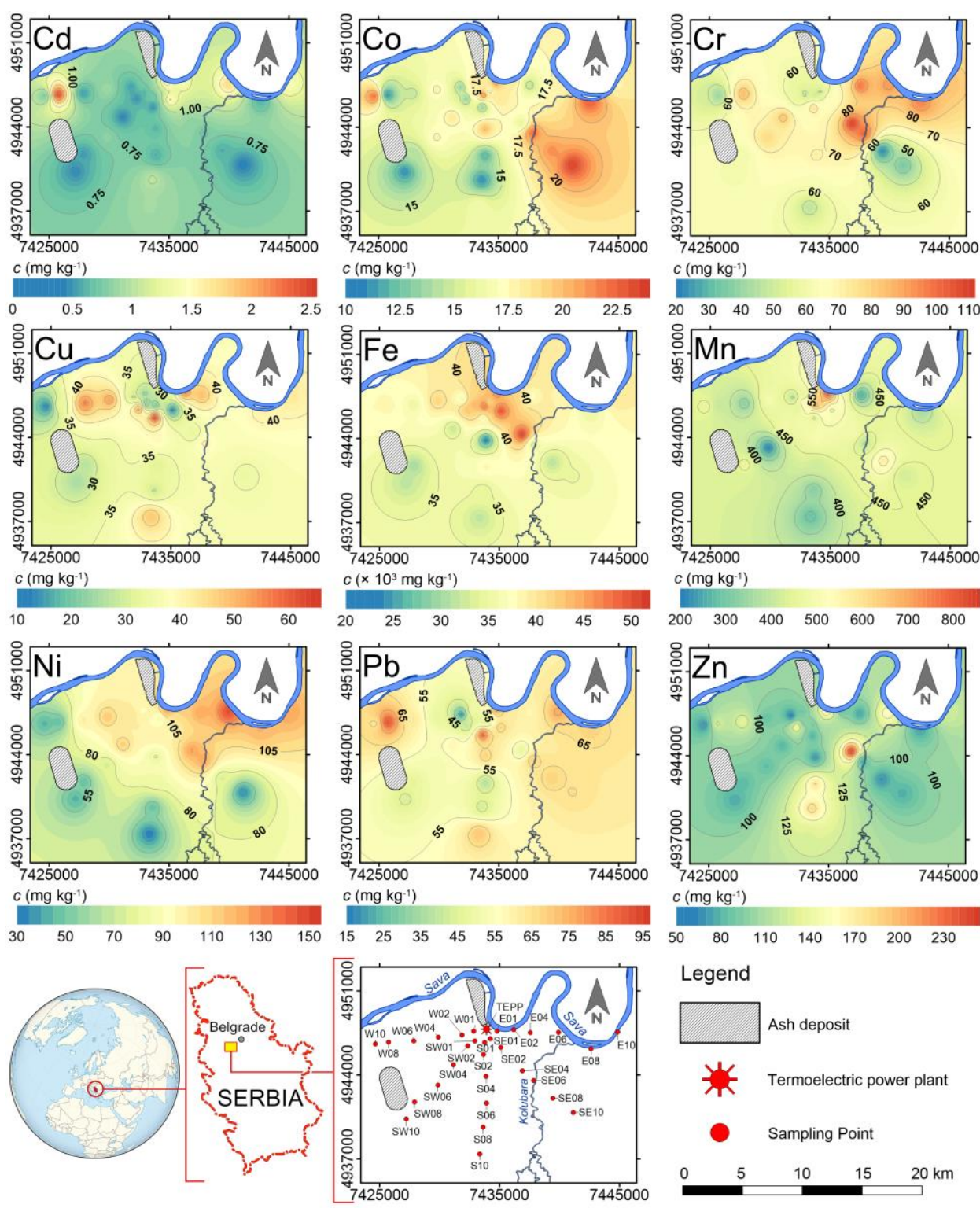

Fig. 2 Spatial distribution of analyzed heavy metals in topsoil from the study area (GaussKrüger coordinate system. 7. meridian zone)

The concentration of $\mathrm{Cr}$ and $\mathrm{Ni}$ seems to be strongly influenced by the geology of the study area due to their similar distribution patterns. The highest concentrations were found very close to the Sava and Kolubara River. Alluvial sediments of these rivers were developed on ultramafic rocks, and higher geochemical content of $\mathrm{Cr}$ and $\mathrm{Ni}$ has been already reported [32]. On the other hand, chemical analysis of lignite used in TEPP "Nikola 
Tesla A" showed high content of $\mathrm{Ni}, \mathrm{Cr}$ and $\mathrm{Cu}$ and their enrichment in fly ash [33]. That may imply that geochemical concentrations of $\mathrm{Cr}$ and $\mathrm{Ni}$ could be elevated due to the TEPP activity.

The existence of certain hotspots in the western part of the study area common for $\mathrm{Cu}$ and $\mathrm{Pb}$, and partially for $\mathrm{Cd}, \mathrm{Co}$, and $\mathrm{Zn}$ might indicate the impact of other anthropogenic sources. Since this part of the investigated area is an agricultural region based on fruit and vegetable growing, the application of phosphate and other fertilizers, as well as pesticides and foliage sprays, can be a huge source of $\mathrm{Cd}, \mathrm{Pb}, \mathrm{Cu}, \mathrm{Co}$ and $\mathrm{Zn}[25,34]$. Furthermore, high levels of $\mathrm{Pb}$ at those sites are probably due to vehicular related emissions from dense traffic network of local roads, as a result of the long use of petrol with lead additives in Serbia in the past.

\subsection{Health risk analysis}

The magnitudes of chronic non-carcinogenic health issues are summarized in Table 4. As it can be seen, the risk from the ingestion of soil particles by children and adults comprises almost whole cumulative $H I$. Dermal risk exists only for the exposition to $\mathrm{Cd}$ in soil, and it is negligible in both categories $\left(4 \times 10^{-9}\right.$ to 0.003$)$. The risk arising from inhalation exposure is not respective because calculated $H I$ is so benevolent with a maximal value of $1 \times 10^{-8}$. This is consistent with the conclusion obtained by Tang et al. in the study of children's exposure to heavy metals in soils around the coal-fired TEPP in China (Huainan City) [8].

Although none of $H Q$ for any single heavy metal was above the reference value of one, aggregate $H I$ for children fell in the range from 1.040 to 2.604 (mean 1.793). Cobalt, $\mathrm{Fe}$, and $\mathrm{Mn}$ were identified as contaminants of most concern with $H I$ values ranged between 0.110 and 0.441 for Mn, 0.419 and 0.936 for Fe, and 0.465 and 1.000 for Co. All of them are considered essential nutrients, but their gastrointestinal intake in higher concentration may cause adverse health effects. In already mentioned study of Tang et al. the total $\mathrm{HI}$ for children due to $\mathrm{As}, \mathrm{Cd}, \mathrm{Cr}, \mathrm{Cu}, \mathrm{Mn}, \mathrm{Ni}, \mathrm{Pb}, \mathrm{V}$, and $\mathrm{Zn}$ in soil was 1.502 , and excluding $H Q$ for As and $\mathrm{V}$ it was 0.545 which is lower than $H I$ obtained in this research, but without contribution from $\mathrm{Co}$ and $\mathrm{Fe}$ [8].

It is known that oral Co exposure in humans can induce respiratory, cardiovascular, gastrointestinal, hematological, hepatic, renal, endocrine, dermal, ocular, hypothermic, and body weight effects. Available data have not clearly defined whether a risk for children is greater than for adults from exposure to Co [35]. The different studies conducted in the world have shown that average Co intake varied among countries. It is estimated to be $0.12 \mathrm{mg} \mathrm{day}^{-1}$ in the United Kingdom, 5-40 $\mu \mathrm{g} \mathrm{day}^{-1}$ in the US, $11 \mu \mathrm{g} \mathrm{day}^{-1}$ in Canada and $29 \mu \mathrm{g} \mathrm{day}^{-1}$ in France [36]. Calculated $C D I_{\text {ing }}$ for the highest Co concentration in this research was $0.3 \mu \mathrm{g} \mathrm{kg} \mathrm{day}{ }^{-1}$, and the ingestion of total Co content by $15 \mathrm{~kg}$ child would result in a daily intake of $4.5 \mu \mathrm{g} \mathrm{day}^{-1}$. This is still less than reported daily intakes for mentioned countries and allows additional intake through the food. All things considered, although the maximal value of $H I$ for Co in soil was 1 , likely, Co would not provoke adverse effects in children. 
Table 4 The potential non-carcinogenic risk for resident population due to minimal, mean and maximal heavy metal contents in soil

\begin{tabular}{|c|c|c|c|c|c|c|c|c|c|}
\hline \multicolumn{2}{|c|}{ Heavy metal } & \multicolumn{4}{|c|}{ Children } & \multicolumn{4}{|c|}{ Adults } \\
\hline & & $H Q_{\text {ing }}$ & $H Q_{\text {inh }}$ & $H Q_{\text {derm }}$ & $H I$ & $H Q_{\text {ing }}$ & $H Q_{\text {inh }}$ & $H Q_{\text {derm }}$ & $H I$ \\
\hline \multirow[t]{3}{*}{$\mathrm{Cd}$} & $\min$ & 0.005 & $2 \times 10^{-11}$ & $5 \times 10^{-4}$ & 0.006 & $5 \times 10^{-4}$ & $2 \times 10^{-11}$ & $8 \times 10^{-5}$ & $6 \times 10^{-4}$ \\
\hline & mean & 0.011 & $5 \times 10^{-11}$ & 0.001 & 0.012 & 0.001 & $5 \times 10^{-11}$ & $2 \times 10^{-4}$ & 0.001 \\
\hline & $\max$ & 0.031 & $1 \times 10^{-10}$ & 0.003 & 0.034 & 0.003 & $1 \times 10^{-10}$ & $5 \times 10^{-4}$ & 0.003 \\
\hline \multirow[t]{3}{*}{$\mathrm{Co}$} & $\min$ & 0.465 & $1 \times 10^{-9}$ & - & 0.465 & 0.044 & $1 \times 10^{-9}$ & - & 0.044 \\
\hline & mean & 0.729 & $2 \times 10^{-9}$ & - & 0.729 & 0.068 & $2 \times 10^{-9}$ & - & 0.068 \\
\hline & $\max$ & 1.000 & $2 \times 10^{-9}$ & - & 1.000 & 0.094 & $2 \times 10^{-9}$ & - & 0.094 \\
\hline \multirow[t]{3}{*}{$\mathrm{Cr}(\mathrm{VI})$} & $\min$ & 0.013 & $2 \times 10^{-11}$ & - & 0.013 & 0.001 & $2 \times 10^{-11}$ & - & 0.001 \\
\hline & mean & 0.041 & $5 \times 10^{-11}$ & - & 0.041 & 0.004 & $5 \times 10^{-11}$ & - & 0.004 \\
\hline & $\max$ & 0.067 & $9 \times 10^{-11}$ & - & 0.067 & 0.006 & $9 \times 10^{-11}$ & - & 0.006 \\
\hline \multirow[t]{3}{*}{$\mathrm{Cu}$} & $\min$ & 0.004 & - & - & 0.004 & $4 \times 10^{-4}$ & - & - & $4 \times 10^{-4}$ \\
\hline & mean & 0.012 & - & - & 0.012 & 0.001 & - & - & 0.001 \\
\hline & $\max$ & 0.021 & - & - & 0.021 & 0.002 & - & - & 0.002 \\
\hline \multirow[t]{3}{*}{$\mathrm{Fe}$} & $\min$ & 0.419 & - & - & 0.419 & 0.039 & - & - & 0.039 \\
\hline & mean & 0.695 & - & - & 0.695 & 0.065 & - & - & 0.065 \\
\hline & $\max$ & 0.936 & - & - & 0.936 & 0.088 & - & - & 0.088 \\
\hline \multirow[t]{3}{*}{$\mathrm{Mn}$} & $\min$ & 0.110 & $2 \times 10^{-9}$ & - & 0.110 & 0.010 & $2 \times 10^{-9}$ & - & 0.010 \\
\hline & mean & 0.242 & $5 \times 10^{-9}$ & - & 0.242 & 0.023 & $5 \times 10^{-9}$ & - & 0.023 \\
\hline & $\max$ & 0.441 & $9 \times 10^{-9}$ & - & 0.441 & 0.041 & $9 \times 10^{-9}$ & - & 0.041 \\
\hline \multirow[t]{3}{*}{$\mathrm{Ni}$} & $\min$ & 0.020 & $2 \times 10^{-10}$ & - & 0.020 & 0.002 & $2 \times 10^{-10}$ & - & 0.002 \\
\hline & mean & 0.058 & $6 \times 10^{-10}$ & - & 0.058 & 0.005 & $6 \times 10^{-10}$ & - & 0.005 \\
\hline & $\max$ & 0.094 & $9 \times 10^{-10}$ & - & 0.094 & 0.009 & $9 \times 10^{-10}$ & - & 0.009 \\
\hline \multirow[t]{3}{*}{$\mathrm{Zn}$} & $\min$ & 0.003 & - & - & 0.003 & $2 \times 10^{-4}$ & - & - & $2 \times 10^{-4}$ \\
\hline & mean & 0.005 & - & - & 0.005 & $4 \times 10^{-4}$ & - & - & $4 \times 10^{-4}$ \\
\hline & $\max$ & 0.011 & - & - & 0.011 & 0.001 & - & - & 0.001 \\
\hline \multirow[t]{3}{*}{$H I$} & $\min$ & 1.039 & $4 \times 10^{-9}$ & $5 \times 10^{-4}$ & 1.040 & 0.097 & $4 \times 10^{-9}$ & $8 \times 10^{-5}$ & 0.097 \\
\hline & mean & 1.792 & $7 \times 10^{-9}$ & 0.001 & 1.793 & 0.168 & $7 \times 10^{-9}$ & $2 \times 10^{-4}$ & 0.168 \\
\hline & $\max$ & 2.601 & $1 \times 10^{-8}$ & 0.003 & 2.604 & 0.244 & $1 \times 10^{-8}$ & $5 \times 10^{-4}$ & 0.244 \\
\hline
\end{tabular}

The US EPA derived RfD of $0.14 \mathrm{mg} \mathrm{kg}^{-1} \mathrm{day}^{-1}$ for the total oral intake of Mn [37]. By strictly following the value of $\mathrm{Mn}$ in the soil of the study area there would not be any significant risk, but instead of this value $R f D$ of $0.024 \mathrm{mg} \mathrm{kg}^{-1} \mathrm{day}^{-1}$ was used for the nonfood items. This is also proposed by US EPA due to numerous uncertainties regarding the risk associated with $\mathrm{Mn}$, and likely due to the strong homeostatic control of $\mathrm{Mn}$ absorption [22]. Studies conducted on children have indicated that extremely high doses may induce deleterious effects on the central nervous system. The tolerable upper intake level (UL) for $\mathrm{Mn}$, for children, varies from 2 to $9 \mathrm{mg} \mathrm{day}^{-1}$ depending on the age and body weight [38]. Obtained $C D I_{\text {ing }}$ for children in this work for the highest $\mathrm{Mn}$ level in soil was $0.0106 \mathrm{mg} \mathrm{kg} \mathrm{day}^{-1}$, which would result in a case of $15 \mathrm{~kg}$ child with a daily intake of $0.159 \mathrm{mg} \mathrm{Mn}$. Such intake is well below the lowest UL, so the risk of harmful effects due to excess Mn intake appears to be very low.

Iron is a component of many proteins, including enzymes and hemoglobin, but it also can be damaging when it accumulates in the body. The Fe content of the body is highly conserved because the body normally absorbs less Fe if its stores are full. For this reason it is important to perform a risk assessment of such an element. Vomiting and diarrhea 
characterize the initial stages of intoxication, and later toxicity is expressed in the cardiovascular, central nervous system, kidney, liver, and hematologic organ systems. First symptoms appear with doses between 20 and $60 \mathrm{mg} \mathrm{kg}^{-1}$ [38]. Lethal doses of Fe are in the range of 200-300 $\mathrm{mg} \mathrm{kg}^{-1}$ [39]. The value of UL for infants and children up to the age of 13 is $40 \mathrm{mg} \mathrm{day}^{-1}$, and for adolescents (age of 14-18) is $45 \mathrm{mg} \mathrm{day}^{-1}$ [38]. Comparing to those values, calculated maximal $C D I_{\text {ing }}$ for children for $\mathrm{Fe}$ in the soil of the study area $\left(0.486 \mathrm{mg} \mathrm{kg}^{-1}\right.$ day $\left.^{-1}\right)$ will yield a daily $\mathrm{Fe}$ intake of $7.29 \mathrm{mg} \mathrm{day}^{-1}$, which is approximately $56 \%$ of the lowest UL recommended.

The values for $H Q$ for adults of all heavy metals were below the threshold value of one. The $H I$ was ranged from 0.097 to 0.244 which indicates negligible risk level.

$\mathrm{Pb}$ toxicity has been known ever since this element is omitted from the non-cancerogenic risk assessment. Lead is a systemic poison with multisystem toxicity that affects the gastrointestinal tract, kidneys, hematopoietic, cardiovascular, nervous, immune, and reproductive system. Studies of $\mathrm{Pb}$ toxicity have not established a 'safe' exposure limit for $\mathrm{Pb}$, therefore, the US EPA has not established an RfD for lead [40]. Young children are most vulnerable to $\mathrm{Pb}$ toxic effects due to their rapid growth rate, development of central nervous systems and substantially higher ability to absorb $\mathrm{Pb}$ than adults. In general, approximately $10-15 \%$ of $\mathrm{Pb}$ ingested by adult humans is absorbed, whereas in children this value may be as high as $50 \%$. More than $90 \%$ of inhaled $\mathrm{Pb}$ particles deposited in the lower respiratory organs enter the bloodstream. Inorganic $\mathrm{Pb}$ is not efficiently dermally absorbed and this route does not contribute markedly to the total body $\mathrm{Pb}$ burden [22]. Peripheral nerve dysfunction occurs at blood $\mathrm{Pb}$ levels of $30-50 \mu \mathrm{g} \mathrm{dm}^{-3}$, and peripheral nerve damage at $400-600 \mu \mathrm{g} \mathrm{dm}^{-3}$. The primary target for $\mathrm{Pb}$ is the central nervous system. Irreversible brain damage has been observed at blood $\mathrm{Pb}$ levels exceeding $1000 \mu \mathrm{g} \mathrm{dm}^{-3}$ in adults and at 800 $1000 \mu \mathrm{g} \mathrm{dm}^{-3}$ in children [22]. The calculated $C D I_{\text {ing }}$ for maximal $\mathrm{Pb}$ concentration in the soil for children and adults in this work was $1.2 \times 10^{-3} \mathrm{mg} \mathrm{kg} \mathrm{day}^{-1}$, and $1.1 \times 10^{-4} \mathrm{mg} \mathrm{kg} \mathrm{day}^{-1}$. In the worst-case scenario, assuming that total volume of blood in $15 \mathrm{~kg}$ child is $1.125 \mathrm{dm}^{-3}$, and $100 \% \mathrm{~Pb}$ bioavailability, and if all $\mathrm{Pb}$ from soil would enter the bloodstream, the resulting blood level would be $15.6 \mu \mathrm{g} \mathrm{dm}^{-3}$ which would have not been enough to cause any severe health effect in children.

The cancer risks are quantified in Table 5. Among heavy metals measured, only Cd, $\mathrm{Co}, \mathrm{Cr}(\mathrm{VI}), \mathrm{Ni}$ and $\mathrm{Pb}$ are classified as human carcinogens [22]. The total cancer risk in the present study ranged from $1.04 \times 10^{-5}$ to $5.24 \times 10^{-5}$. The US EPA considers cancer risk below $10^{-6}$ to be negligibly small, and risk of $10^{-4}$ to be sufficiently large that remediation is desirable. Cancer risk between $10^{-6}$ and $10^{-4}$ is generally considered acceptable. The exposure route that has the highest contribution to the $E L C R_{\text {total }}$ appears to be the ingestion of soil, followed by an insignificant contribution from inhalation. There is no risk induced by dermal exposure. 
Table 5 Carcinogenic lifetime risk for the resident population based on minimal, mean and maximal heavy metal concentration in soil

\begin{tabular}{llcccc}
\hline Heavy metal & & $E L C R_{\text {ing }}$ & $E L C R_{\text {inh }}$ & $E L C R_{\text {derm }}$ & $E L C R_{\text {total }}$ \\
\hline $\mathrm{Cd}$ & $\min$ & - & $1.55 \times 10^{-16}$ & - & $1.55 \times 10^{-16}$ \\
& $\operatorname{mean}$ & - & $3.36 \times 10^{-16}$ & - & $3.36 \times 10^{-16}$ \\
& $\max$ & - & $9.24 \times 10^{-16}$ & - & $9.24 \times 10^{-16}$ \\
$\mathrm{Co}$ & $\min$ & - & $2.06 \times 10^{-14}$ & - & $2.06 \times 10^{-14}$ \\
& $\operatorname{mean}$ & - & $3.22 \times 10^{-14}$ & - & $3.22 \times 10^{-14}$ \\
& $\max$ & - & $4.43 \times 10^{-14}$ & - & $4.43 \times 10^{-14}$ \\
$\mathrm{Cr}(\mathrm{VI})$ & $\min$ & $1.02 \times 10^{-5}$ & $1.52 \times 10^{-13}$ & - & $1.02 \times 10^{-5}$ \\
& $\operatorname{mean}$ & $3.10 \times 10^{-5}$ & $4.63 \times 10^{-13}$ & - & $3.10 \times 10^{-5}$ \\
$\mathrm{Ni}$ & $\max$ & $5.13 \times 10^{-5}$ & $7.66 \times 10^{-13}$ & - & $5.13 \times 10^{-5}$ \\
& $\min$ & - & $1.73 \times 10^{-15}$ & - & $1.73 \times 10^{-15}$ \\
& $\operatorname{mean}$ & - & $4.92 \times 10^{-15}$ & - & $4.92 \times 10^{-15}$ \\
$\mathrm{~Pb}$ & $\max$ & - & $8.01 \times 10^{-15}$ & - & $8.01 \times 10^{-15}$ \\
& $\min$ & $2.07 \times 10^{-7}$ & $4.25 \times 10^{-17}$ & - & $2.07 \times 10^{-7}$ \\
& $\operatorname{mean}$ & $7.10 \times 10^{-7}$ & $1.46 \times 10^{-16}$ & - & $7.10 \times 10^{-7}$ \\
\hline$E L C R_{\text {total }}$ & $\max$ & $1.12 \times 10^{-6}$ & $2.30 \times 10^{-16}$ & - & $1.12 \times 10^{-6}$ \\
\hline & $\min$ & $1.04 \times 10^{-5}$ & $1.75 \times 10^{-13}$ & - & $1.04 \times 10^{-5}$ \\
& $\operatorname{mean}$ & $3.17 \times 10^{-5}$ & $5.01 \times 10^{-13}$ & - & $3.18 \times 10^{-5}$ \\
& $\max$ & $5.24 \times 10^{-5}$ & $8.19 \times 10^{-13}$ & - & $5.24 \times 10^{-5}$ \\
\hline
\end{tabular}

According to data obtained from the Institute of Public Health of Serbia, the real standardized cancer incidence for 2013 in Kolubara County (where study area belongs) was $3.24 \times 10^{-3}$ for males and $2.40 \times 10^{-3}$ for females [41]. These values are very high in comparison to the risk assessed in this study. Therefore, the risk provoked by exposure to heavy metals in the soil makes a portion of the real cancer risk that is completely insignificant.

The total cancer risk from the ingestion of $\mathrm{Cr}(\mathrm{VI})$ was between $1.02 \times 10^{-5}$ and $5.13 \times 10^{-5}$, which means that almost all $E L C R_{\text {total }}$ consists of risk coming from oral intake of this element. These findings should be taken with caution. Namely, $\mathrm{Cr}(\mathrm{VI})$ is known to be carcinogenic in humans by the inhalation route associated with increased lung cancer risk among workers in certain industries. Nevertheless, $\mathrm{Cr}(\mathrm{VI})$ by ingestion is also likely to be carcinogenic. Accordingly, a more health-protective approach for cancer risk assessment due to $\mathrm{Cr}(\mathrm{VI})$ exposure via ingestion is being applied. In that respect, $S F$ of $0.5 \mathrm{mg}^{-1} \mathrm{~kg}$ day was used for the calculation of oral cancer risk [42]. This figure is quite low and primarily was developed for drinking water. Under those circumstances, it is likely that oral $\mathrm{Cr}(\mathrm{VI})$ cancer risk is overestimated.

The second-largest contributor to the overall cancer risk is $\mathrm{Pb}$. The most common cancers provoked by $\mathrm{Pb}$ exposure are lung and brain cancer [22]. Although the risk caused by this element is two orders of magnitude lower than in the case of $\mathrm{Cr}$, it should not be ignored since the calculated lifetime risk for maximal $\mathrm{Pb}$ content is $1.12 \times 10^{-6}$, and exceeded general guidance risk value of $10^{-6}$.

In the end, it is important to realize that the US EPA model used for risk assessment assumes an absorption efficiency of $100 \%$ for all heavy metal concentrations used. Since the concentrations determined in this work were total concentrations, the final results have to be considered as very conservative because no total concentrations are bioavailable to humans. 


\section{CONCLUSION}

This study evaluated the potential ecological and human health risk due to heavy metals in soils in the proximity of the largest Serbian TEPP and provides baseline data regarding the distribution of heavy metals in soil. The analysis of the potential ecological risk showed that soil is considered a relatively low to moderate ecological risk. Contamination was observed in the studied soil samples, most of all with $\mathrm{Cd}$, following with $\mathrm{Ni}, \mathrm{Cu}$, and $\mathrm{Pb}$. Analysis of the heavy metals spatial distribution revealed that soil in proximity to the TEPP and the downwind area had a higher level of analyzed heavy metals, while soil away from the TEPP was under greater influence from natural processes and other anthropogenic impacts (agriculture and traffic). The estimated carcinogenic risk in this research is within the acceptable range. Figures for non-carcinogenic risk suggest that adults are not endangered due to heavy metals in soil, while the children population is under elevated risk from deleterious health effects. Ingestion of soil was identified as a primary pathway of heavy metal sources which harm human health. This study may be valuable data source for long-term monitoring of soil quality and may provide a basis for the development of further activities related to the prevention of excessive exposure of humans, especially children, to heavy metals present in the soil. A future study applying a sequential extraction procedure is recommended to determine the proportion of the total metal pool that might be bioavailable.

Acknowledgment: This work was partially supported by the Ministry of Education, Science and Technological Development of the Republic of Serbia (project III43009).

\section{REFERENCES}

1. International Energy Agency: World Energy Outlook 2014, Paris, International Energy Agency, 2014.

2. Stalikas C. D., Chaidou C. I. and Pilidis G. A.: Enrichment of PAHs and heavy metals in soils in the vicinity of the lignite-fired power plants of West Macedonia (Greece), Sci. Total Environ., Vol. 204, pp. 135-146, 1997.

3. Çayır A., Belivermiş M., Kılıç Ö., Coşkun M. and Coşkun M.: Heavy metal and radionuclide levels in soil around Afsin-Elbistan coal-fired thermal power plants, Turkey, Environ. Earth Sci., Vol. 67, pp. 1183-1190, 2012.

4. Adriano D. C., Wenzel W. W., Vangronsveld J. and Bolan N. S.: Role of assisted natural remediation in environmental cleanup, Geoderma, Vol. 122, pp. 121-142, 2004.

5. Qiao M., Cai C., Huang Y., Liu Y., Lin A. and Zheng Y.: Characterization of soil heavy metal contamination and potential health risk in metropolitan region of northern China, Environ. Monit. Assess., Vol. 172, pp. 353-365, 2011.

6. Raja R. and others: Impairment of soil health due to fly ash-fugitive dust deposition from coal-fired thermal power plants, Environ. Monit. Assess., Vol. 187, p. 679, 2015.

7. Zacháry D., Jordan G., Völgyesi P., Bartha A. and Szabó C.: Urban geochemical mapping for spatial risk assessment of multisource potentially toxic elements - A case study in the city of Ajka, Hungary, J. Geochemical Explor., Vol. 158, 2015.

8. Tang Q., Liu G., Zhou C., Zhang H. and Sun R.: Distribution of environmentally sensitive elements in residential soils near a coal-fired power plant: Potential risks to ecology and children's health, Chemosphere, Vol. 93, pp. 2473-2479, 2013.

9. Dragović S. and others: Trace element distribution in surface soils from a coal burning power production area: A case study from the largest power plant site in Serbia, Catena, Vol. 104, pp. 288-296, 2013.

10. Keshav Krishna A. and Rama Mohan K.: Distribution, correlation, ecological and health risk assessment of heavy metal contamination in surface soils around an industrial area, Hyderabad, India, Environ. Earth Sci., Vol. 75, p. 411, 2016. 
11. Okedeyi O. O., Dube S., Awofolu O. R. and Nindi M. M.: Assessing the enrichment of heavy metals in surface soil and plant (Digitaria eriantha) around coal-fired power plants in South Africa, Environ. Sci. Pollut. Res., Vol. 21, pp. 4686-4696, 2014.

12. Ministry of Mining and Energy of the Republic of Serbia: The Energy Sector Development Strategy of the Republic of Serbia by 2025 (Draft), Belgrade, National Assembly of the Republic of Serbia, 2014.

13. Popovic A., Djordjevic D. and Polic P.: Trace and major element pollution originating from coal ash suspension and transport processes, Environ. Int., Vol. 26, pp. 251-255, 2001.

14. Powerplants Nikola Tesla: TPP 'Nikola Tesla A', Obrenovac, 2016. [Online]. Available: http://www.tent.rs/ en/tent-a. [Accessed: 01-Oct-2016].

15. Institute for Informatics and Statistics: Statistical Yearbook of Belgrade 2012, Belgrade, Institute for Informatics and Statistics, 2013.

16. Tanić M. N., Ćujić M. R., Gajić B. A., Daković M. Z. and Dragović S. D., Content of the potentially harmful elements in soil around the major coal-fired power plant in Serbia: relation to soil characteristics, evaluation of spatial distribution and source apportionment, Environ. Earth Sci., Vol. 77, p. 28, 2018.

17. Salminen R., Batista M. J., Bidovec M., Demetriades A., De Vivo B. and De Vos W.: Geochemical Atlas of Europe. Part 1 - Background Information, Methodology and Maps, Espoo, Geological Survey of Finland, 2005.

18. Zoller A. W. H., Gladney E. S. and Duce R. A.: Atmospheric Concentrations and Sources of Trace Metals at the South Pole, Science, Vol. 183, pp. 198-200, 1974.

19. Muller G.: Index of geoaccumulation in sediments of the Rhine river, J. Geol., vol. 2, pp. 108-118, 1969.

20. Hakanson L.: An ecological risk index for aquatic pollution control. A sedimentological approach, Water Res., Vol. 14, pp. 975-1001, 1980.

21. Tomlinson D. L., Wilson J. G., Harris C. R. and Jeffrey D. W.: Problems in the assessment of heavymetal levels in estuaries and the formation of a pollution index, Helgoländer Meeresuntersuchungen, Vol. 33, pp. 566-575, 1980.

22. US Department of Energy: RAIS The Risk Assessment Information System, 2009. [Online]. Available: https://rais.ornl.gov/. [Accessed: 11-Jul-2017].

23. The Council of the European Communities: Council directive on the protection of the environment, and in particular of the soil, when sewage sludge is used in agriculture (86/278/EEC), Official Journal of the European Communities, No. L181/6, 1986.

24. Dutch Ministry of Infrastructure and the Environment: Circular on target values and intervention values for soil remediation, Netherlands Government Gazette, No. 39, 2000.

25. Petrotou A., Skordas K., Papastergios G. and Filippidis A.: Factors affecting the distribution of potentially toxic elements in surface soils around an industrialized area of northwestern Greece, Environ. Earth Sci., Vol. 65, pp. 823-833, 2012.

26. Keegan T. J. and others: Dispersion of As and selected heavy metals around a coal-burning power station in central Slovakia, Sci. Total Environ., Vol. 358, pp. 61-71, 2006.

27. Nica Badea D.: Emission Impact Assessment from Turceni Power Plant on the Heavy Metal Pollution of the Soil, Fiabil. şi Durabilitate, Vol. 1, pp. 255-261, 2017.

28. Medunić G. and others: Sulphur and heavy metal pollution of the coal-based city soil (Labin, Croatia), Goldschmidt Conference Abstracts, p. 2041, 2016.

29. Patel K., Sharma R., Dahariya N., Patel R., Blazhev B. and Matini L.: Black Carbon and Heavy Metal Contamination of Soil, Polish J. Environ. Stud., Vol. 25, pp. 717-724, 2016.

30. Kabata-Pendias A.: Trace elements in soils and plants, Boca Raton, CRC Press, 2011.

31. BiPRO: Airborne cadmium emissions from coal fired electricity generation in the European Union Report, Submitted by BiPRO for Nanoco Technologies Ltd., 2016.

32. Serbian Environmental Protection Agency: The report on the status of soil in the Republic of Serbia, Belgrade, Ministry of Energy, Development and Spatial Planning, 2009.

33. Pavlović P., Mitrović M. and Djurdjević L.: An Ecophysiological Study of Plants Growing on the Fly Ash Deposits from the 'Nikola Tesla-A' Thermal Power Station in Serbia, Environ. Manage., Vol. 33, pp. 654$663,2004$.

34. Facchinelli A., Sacchi E. and Mallen L.: Multivariate statistical and GIS-based approach to identify heavy metal sources in soils, Environ. Pollut., Vol. 114, pp. 313-324, 2001.

35. Agency for Toxic Substances and Disease Registry: Toxicological Profile for Cobalt, Atlanta, Agency for Toxic Substances and Disease Registry, 2004.

36. Kim J. H.: Cobalt and inorganic cobalt compounds, Concise International Chemical Assessment Document 69, Stuttgart, World Health Organization, 2006. 
37. US Environmental Protection Agency: Integrated Risk Information System (IRIS) Chemical Assessment Summary - Manganese, 2002, [Online]. Available: https:/cfpub.epa.gov/ncea/iris2/chemicalLanding.cfm? substance_nmbr=373. [Accessed: 17-Jul-2017].

38. Institute of Medicine Food and Nutrition Board: Dietary Reference Intakes for Vitamin A, Vitamin K, Arsenic, Boron, Chromium, Copper, Iodine, Iron, Manganese, Molybdenum, Nickel, Silicon, Vanadium, and Zinc: a Report of the Panel on Micronutrients, Washington, National Academy Press, 2001.

39. US Environmental Protection Agency: Provisional Peer Reviewed Toxicity Values for Iron and Compounds, Cincinnati, US Environmental Protection Agency, 2006.

40. US Environmental Protection Agency: Integrated Risk Information System, 2013, [Online]. Available: https://www.epa.gov/iris. [Accessed: 12-Jul-2017].

41. Institute of Public Health of Serbia: Health Statistical Yearbook of Republic Serbia 2015, Belgrade, Institute of Public Health of Serbia, 2016.

42. California Environmental Protection Agency: Consolidated table of OEHHA/ARB approved risk assessment health values, 2017, [Online]. Available: https://www.arb.ca.gov/toxics/healthval/ healthval.htm. [Accessed: 20-Jul-2017].

\section{PROCENA EKOLOŠKOG I ZDRAVSTVENOG RIZIKA OD TEŠKIH METALA U ZEMLJIŠTU U OKOLINI TERMOELEKTRANE „NIKOLA TESLA A“}

Ekološki i zdravstveni rizik su procenjeni u odnosu na koncentracije odabranih teških metala $(\mathrm{Cd}$, $\mathrm{Co}, \mathrm{Cr}, \mathrm{Cu}, \mathrm{Fe}, \mathrm{Mn}, \mathrm{Ni}, \mathrm{Pb}$ i $\mathrm{Zn})$ u trideset površinskih uzoraka zemljišta iz okoline najveće termoelektrane u Srbiji. Ekološki rizik je procenjen putem različitih pokazatelja zagađenja i njihove vrednosti pokazuju niski do srednji ekološki rizik. Rizik po zdravlje usled izlaganja stanovništva teškim metalima u zemljištu je izračunat primenom modela Agencije za zaštitu životne sredine Sjedinjenih Američkih Država. Ingestija zemljišta je identifikovana kao najvažniji put izlaganja. Procena rizika je pokazala da ekspozicija Co, Fe i Mn rezultuje neprihvatljivim nekancerogenim rizikom za decu. $\mathrm{Cr} i$ $\mathrm{Pb}$ su bili jedini elementi koji su doprinosili u većem obimu kancerogenom riziku, ali je ukupan kancerogeni rizik bio u granicama tolerantnog.

Ključne reči: zagađenje, zemljište, teški metal, pokazatelji zagađenja, Informacioni sistem za procenu rizika, Nikola Tesla A 